The major cause of death of patients in this series was infection. The nature and source of the infecting organisms and the results of treatment are described.

ADDENDUM.-The renal homograft of Case 2 was recently biopsied at open operation 1 year 10 months after transplantation. Apart from a few foci of superficial cortical scarring, moderate hyperplasia of all the juxtaglomerular bodies, and glomerular hypertrophy, this kidney appeared normal. There were no vascular or glomerular changes visible on light microscopy.

We wish to thank all those clinicians at St. Mary's and other hospitals for their co-operation in providing donors, and Dr. P. Barkham, Dr. I. Chanarin, and Dr. B. J. Houghton for their help and advice. We are indebted to Sister B. Bates and Sister P. Wall and their staffs, and also Mr. Lowe and his staff, for the care and attention given to the patients. We would also like to thank Dr. P. Baker, Dr. H. M. Leather, and Dr. G. R. Steed, of Plymouth, for their help. The Board of Governors are to be thanked for their generous financial support.

\section{REFERENCES}

Berenbaum, M. C. (1965). Brit. med. Bull., 21, 140.

Brumfitt, W., Leigh, D. A., Percival, A., and Williams, J. D. (1964). Postgrad. med. F., Suppl. 40, p. 55 .

Chanarin, I. (1963). Brit. 7. Haemat., 9, 141

Cha Bennett, M. C. (1962). Brit. med. F., 1, 27.

ossetor, J. B., Gault, M. H., Oliver, J. A., Inglis, F. G., MacKinnon, K. J., and MacLean, L. D. (1964). Canad. med. Ass., F., 91, 733.

Dunea, G., Nakamoto, S., Straffon, R. A, Figueroa, J. E., Versaci, A. A., Shibagaki, M., and Kolff, W. J. (1965). Brit. med. F., 1, 7.

Hamburger, J., Crosnier, J., and Dormont, J. (1964). Ann. N.Y. Acad. Sci., 120, 558.
Hume, D. M., Magee, J. H., Kauffman, H. M., Bower, J. D., Lee, H. M., Cleveland, R. J., and Prout, G. R. (1964). Transplantation, 2, 164. Merrill, J. P., Miller, B. F., and Thorn, G. W. (1955). F. clin. Invest., 34, 327 .

Kauffman, H.' M., Clark, R. F., Magee, J. H., Rittenbury, M. S., Goldsmith, C.' M., Prout, G.'R., and Hume,'D. M. (1964). Surg. Gynec. and Obstet., 119,25.

Küss, R., Teinturier, J., and Milliez, P. (1951). Mém. Acad. Chir., 77,

Lambe, R. F., and Williams, D. C. (1965). Biochem. 7., 95, 847. Lannigan, R., and Meynell, M. J. (1959). 7. clin. Path., 12, 157.

847.
McIntosh, D. A., McPhaul, J. J., Peterson, E. W., Harvin, J. S., Smith, J. R., Cook, F. E., and Humphreys, J. W. (1965). Ұ. Amer. med. Ass., 192, 1171 .

Merrill, J. P., Murray, J. E., Takacs, F. J., Hager, E. B., Wilson, R. E., and Dammin, G. J. (1963). Ibid., 185, 347.

Murray, J. E., Gleason, R., and Bartholomay, A. (1965). Transplantation, 3, 294.

Nakamoto, S., Straffon, R. A., and Kolff, W. J. (1965). F. Amer. med. Ass., 192, 302.

Porter, K. A., Thomson, W. B., Owen, K., Kenyon, J. R., Mowbray, J. F., and Peart, W. S. (1963). Brit. med. F., 2, 639

Peart, W. S., Kenyon, J. R., Joseph, N. H., Hoehn, R. J., and Calne, R. Y. (1964). Ann. N.Y. Acad. Sci., 120, 472.

Rifkind, D., Marchioro, T. L., Waddell, W. R., and Starzl, T. E. (1964a). 7. Amer. med. Ass., 189, 397.

Starzl, T. E., Marchioro, T. L., Waddell, W. R., Rowlands, D. T., and Hill, R. B. (1964b). Ibid., 189, 808 .

Rood, J. J. van, and Leeuwen, A. van (1965). In Histocompatibility Testing, p. 21. National Academy of Sciences, Washington, D.C.

Schreiner, G. E., and Maher, J. F. (1961). Uraemia: Biochemistry, Pathogenesis, and Treatment. Thomas, Springfield, Illinois.

Simonsen, M. (1965). Lancet, 1, 415.

Starzl, T. E., Marchioro, T. L., Porter, K. A., Moore, C. A., Rifkind D., and Waddell, W. R. (1964). Ann. intern. Med., 61, 470. Vredevoe, D. L., Hutt, M. P., Ogden, D. A., D., Herrmann, T. J., (1965). Ann. Surg., 162, 749.

- and Waddell, W. R. (1963). Surg. Gynec. Obstet., 117, 385.

Thomas, L., (1953). Ann. N.Y. Acad. Sci., 56, 799.

Torack, R. M. (1957). Amer. F. Med., 22, 872.

Waller, M., Irby, R., Mullinax, F., and Toone, E. C. (1965). New Engl. f. Med., 273, 12

\title{
Probable Mode of Action of Oral Contraceptives*
}

\author{
EGON DICZFALUSY, $†$ M.D.
}

"What is past is prologue."-Shakespeare, The Tempest.

Brit. med. F., 1965, 2, 1394-1399

At the Fifth International Conference on Planned Parenthood in Tokyo, Pincus (1955) reported an ovulation inhibition by progesterone or norethynodrel ${ }^{1}$ taken orally by women. This report indicated the beginning of a new era in the history of contraception. To-day, some 10 years later, oral contraception is effectively used by at least five million women. However, the exact mechanism of action by which these compounds inhibit fertility is still incompletely understood.

\section{Normal Control of Ovulation}

A discussion of the probable mode of action of oral contraceptives might be facilitated by a brief recapitulation of the present concepts of the normal control of ovulation in the human species. In my interpretation the available evidence on this can be summarized as follows.

During each menstrual cycle the endometrium is built up gradually in order to be prepared for the nidation of the fertilized ovum.

\footnotetext{
* Based on a paper read at the Annual Clinical Meeting of the British Medical Association, Dundee, 1965.

f From the Hormone Laboratory, Department of Women's Diseases, Karolinska sjukhuset, Stockholm, Sweden.

1 The systematic names of the compounds mentioned in this review are given in Table I.
}

This endometrial development is regulated by ovarian steroid hormones: oestrogen during the first, or proliferative, phase, and progesterone +oestrogen during the second, or luteal, phase.

The synthesis and release of these ovarian hormones is regulated by pituitary gonadotrophic hormones-namely, the folliclestimulating hormone (F.S.H.) and the luteinizing hormone (L.H.) (also called interstitial-cell-stimulating hormone (I.C.S.H.)). The role of the third gonadotrophin, luteotrophin (L.T.H.) (also called prolactin), in the control of ovarian activity in the human is obscure.

Under gonadotrophic stimulation an array of follicles are brought to considerable development in each cycle. However, only one of these develops into a Graafian follicle; the others become atretic and rapidly degenerate. The mechanism by which this atretic process is regulated is incompletely understood (see Sturgis, 1961).

The maturing follicle shows an increasing rate of growth during the last few days of the proliferative phase. This is associated with the production of increased amounts of oestrogenic hormones, as reflected, among other things, by an increased urinary excretion of the oestrogens produced by the ovary and of their metabolites (Brown et al., 1959; Diczfalusy and Lauritzen, 1961). The increasing amount of circulating oestrogen induces characteristic morphological changes in the endometrium, vaginal epithelium, and cervical mucus (Diczfalusy and Lauritzen, 1961). The mucus becomes thin and watery and is readily penetrable by sperms.

Under additional gonadotrophic stimulation (characterized by an increased L.H. secretion of relatively limited duration) the Graafian 
follicle ruptures, ovulation takes place, and the ruptured follicle is converted into a corpus luteum, which produces considerable quantities of progesterone. This is reflected inter alia by an increased urinary output of pregnanediol (Loraine, 1958). Howver, the corpus luteum also produces some oestrogen; in the presence of these synergistic amounts of oestrogen, progesterone induces optimal conditions for implantation of the fertilized ovum by converting the endometrium into a secretory (luteal) type. It also alters the vaginal epithelium and cervical mucus: the mucus becomes thick, tacky, and hostile to sperm penetration.

Table I.-Trivial Names Used in the Present Review

Chlormadinone : $17 \alpha$-acetoxy-6-chloro-6-dehydroprogesterone. Ethynodiol diacetate : $17 \alpha$-ethynyl-oestra-4-ene-3 $\beta, 17 \beta$-diol diacetate. Lyndiol: $17 \alpha$-ethynyl-3-deoxo-19-nortestosterone.

Lynoestrenol: $17 \alpha$-ethynyl-17 $\beta$-hydroxyoestr-4-ene.

Norethisterone: $17 \alpha$-ethynyl-19-nortestosterone.

Norethisterone acetate: $17 \alpha$-ethynyl, $17 \beta$-acetoxy-19-notestosterone.

Norethynodrel : $17 \alpha$-ethynyl-17 $\beta$-hydroxyoestra-5(10)-en-3-one.

Provera : $17 \alpha$-acetoxy-6 $\alpha$-methyl progesterone.

The gonadotrophic control of the endocrine activity of the corpus luteum is poorly understood. It is known, however, that the functional life of the corpus luteum is limited, unless it is exposed to a massive gonadotrophic stimulation from the products of conception in the form of chronionic gonadotrophin (Bradbury et al., 1950). Otherwise, some 14 days after ovulation the steroid secretion of the corpus luteum decreases so markedly that the endometrium is left practically without hormonal stimulation. The endometrium is desquamated and its shedding occurs in the form of menstrual bleeding.

The secretion of pituitary gonadotrophins is regulated by hypothalamic centres, and the function of these centres is controlled by the circulating oestrogen and progesterone via a feed-back mechanism. Thus bilateral oophorectomy results in a greatly increased output of pituitary gonadotrophins (Diczfalusy and Heinrichs, 1956 ; Loraine, 1958), whereas huge doses of ovarian steroids (especially of oestrogens) may completely abolish their formation and release (Loraine, 1958 ; Albert, 1961).

However, these are extreme reactions induced by drastic unphysiological alterations. It is generally assumed that the sequential release of gonadotrophins during the menstrual cycle is regulated by more delicate changes in the circulating oestrogen-progesterone ratio. Present knowledge of this mechanism is limited and vague. However, it seems reasonable to assume that the increasing production of oestrogen by the maturing follicle reduces the secretion of F.S.H., as reflected by its diminished urinary excretion in the majority of cycles studied (Brown, 1959 ; Fukushima et al., 1964 ; Stevens and Vorys, 1965a). At the same time the increased oestrogen production stimulates the release of L.H. (Funnell et al., 1951; McArthur et al., 1961). The increased release of L.H. is reflected by the typical mid-cycle rise in urinary L.H. excretion-see Bucholz (1957) Loraine (1958), McArthur et al. (1958), Wide and Gemzell (1962), Brown et al. (1964), Fukushima et al. (1964), Stevens and Vorys (1965a). The ensuing ovulation and corpus luteum formation brings considerable quantities of progesterone into

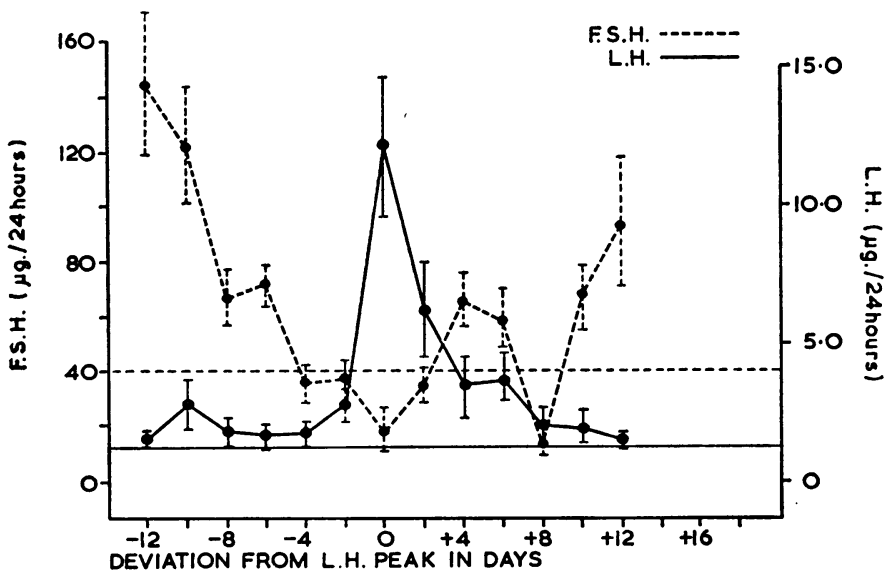

FIG. 1.-Urinary excretion of follicle-stimulating hormone (F.S.H.) and luteinizing hormone (L.H.) in the normal menstrual cycle. (According to Fukushima et al. (1964) modified by Stevens and Vorys (1965a)). circulation; it is assumed that this progesterone acts as an antioestrogen and prevents the continued release of L.H. by circulating oestrogen (Stevens and Vorys, 1965a). Finally, the above-mentioned regression of the corpus luteum results in a diminished production of both oestrogen and progesterone (Loraine, 1958). This withdrawal of steroid seems to stimulate again the release of F.S.H.: a new array of follicles begin to develop.

These sequential changes in urinary F.S.H. and L.H. excretion are illustrated in Fig. 1, which is taken from the paper of Stevens and Vorys (1965a) and is based on the study of 11 normal cycles. It should be pointed out, however, that Schmidt-Elmendorff (1965), in a very careful recent study, found a mid-cycle peak in the urinary excretion of not only L.H., but also of F.S.H. It seems, therefore, that more information is needed on the excretion of F.S.H. and L.H. in the normal cycle.

After this brief recapitulation we have to discuss our major problem-namely, at which stages of the above process oral contraceptives are likely to interefere. The following points of attack (shown schematically in Fig. 2) should be considered.

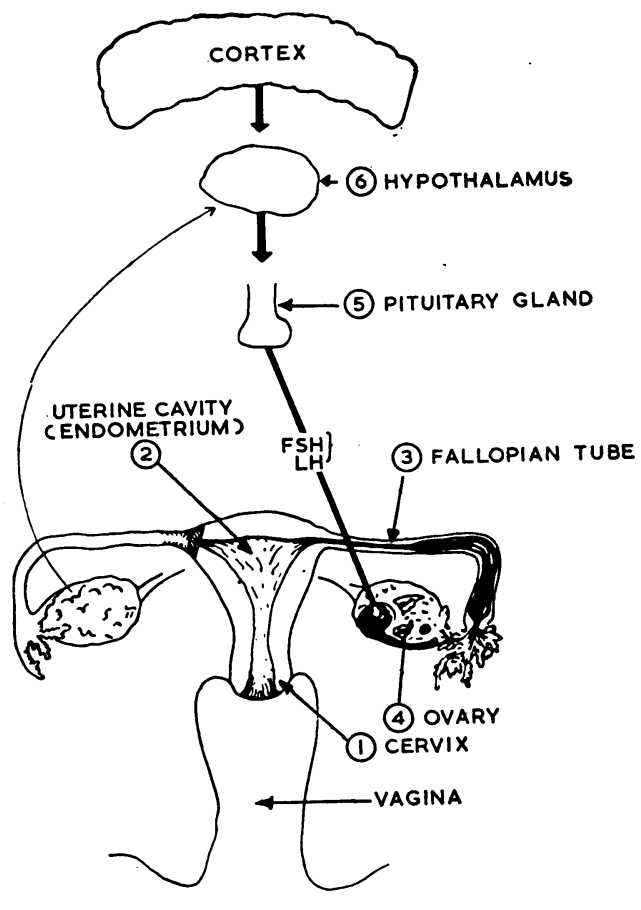

FIG. 2.-Schematic representation of possible points of attack of oral contraceptives.

(1) the gestagen component of the pill is known to change the composition of the cervical mucus (Zañartu, 1964). This change may be enough to inhibit sperm penetration. It is also possible that (2) the endometrial changes induced by the pill interfere with normal implantation. Furthermore, one could even think that (3) the pill acts on the secretion or motility of the Fallopian tube, so that the fertilized ovum reaches the uterine cavity prematurely and fails to implant. Last, but not least, the pill may interfere with ovulation either (4) by inhibiting ovarian response to endogenous gonadotrophins or (5) by inhibiting the secretion of gonadotrophins. In the discussion which follows an attempt is made to marshal the evidence in favour of the various points of attack and to evaluate, so far as this is possible, their relative significance.

\section{Cervical Mucus}

That the cervical mucus might be one of the principal sites of action was suggested by the first studies of Pincus (1956, 1959) and of Ishikawa et al. (1957). These investigators found that no pregnancies occurred in women treated orally with large doses of progesterone, though ovulation was inhibited only in some $70 \%$ of the cases studied. The importance of the changes 
in the cervical mucus was also stressed by Greenblatt (1959). Additional circumstantial evidence suggesting a major part played by the changes in the cervical mucus and/or endometrium comes from the recent study of Rudel and MartinezManautou (1965), who achieved fertility control with a very low level of "luteal supplementation" without inhibiting ovulation. The mechanism of protection in this method-and probably in that of Pincus (1956) and of Ishikawa et al. (1957) -must involve an effect on the cervical mucus and/or endometrium and Fallopian tubes.

More direct evidence is also available, indicating an effect of oral contraceptives on cervical mucus. Zañartu (1964) studied the effect of various oral gestagens on cervical mucus and sperm penetration and found a change towards progestational-like appearance and increased hostility to sperm penetration. Furthermore, Férin (1964) found sperms with progressive motility in only one out of 20 post-coital tests carried out on women treated with Lyndiol.

It appears, therefore, that the induction of progestational changes in the cervical mucus is at least one of the mechanisms of action of oral contraceptives containing a gestagen component.

\section{Endometrial Changes}

Apart from some circumstantial evidence suggesting an effect of chlormadinone on cervical mucus and possibly also on the endometrium, information is scanty on the exact part in fertility control played by the endometrial changes induced by oral contraceptives. The problem is further complicated by the fact that the endometrial changes induced by the "classical" pillthat is, gestagen-oestrogen combinations (Pincus, 1959)-are different from those caused by the sequential $15+5$ days oestrogen-gestagen regime (Maqueo et al., 1964), and both are

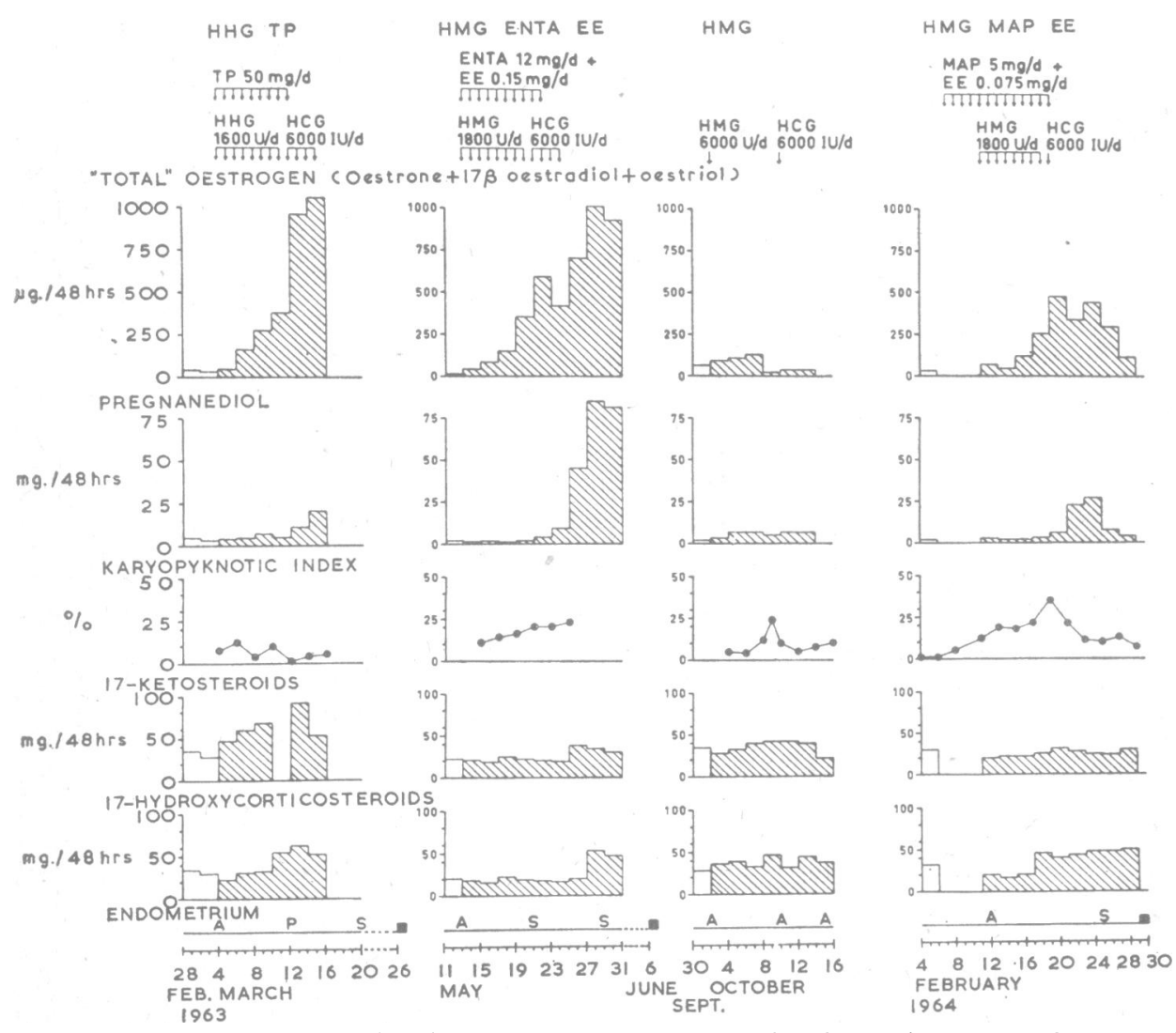

Fic. 3.-Lack of effect of $17 \alpha$-ethynyl,19-nortestosterone acetate + ethynyloestradiol (ENTA + EE) and of $6 \alpha$-methyl,17 $\alpha$-acetoxyprogesterone + ethynyloestradiol (MAP + EE) on the ovarian reaction elicited by the administration of human menopausal gonadotrophin (HMG) to a patient with secondary amenorrhoea. HHG indicates human hypophysial gonadotrophin, TP is testosterone proprionate, whereas A $P$ and $S$ Indicate atrophic, proliferative and secretory endometrium, respectively. The daily dose of HMG $(1,800$ U/d) corresponds to 260 I.U. of F.S.H. and 170 I.U. of L.H. activity. (According to Johannisson et al., 1965.) somewhat different from those obtained with the $10+11$ days' sequential administration (Mears, 1965). Whether the differences in endometrial response to various types of gestagens are significant or not is under debate (Maqueo et al., 1963 ; RiceWray et al., 1963).

Thus it remains to be elucidated whether or not the endometrial changes induced by oral contraceptives are of significance in preventing the implantation of the blastocyst.

\section{Effect on the Fallopian Tubes}

At present no evidence is on record suggesting a direct effect of oral contraceptives on the secretion or motility of the Fallopian tubes. Passage of the fertilized ovum through the Fallopian tube, which occurs while cleavage is in progress, takes at least four to five days (Amoroso, 1952 ; Boyd and Hamilton, 1952 ; Hartman, 1962), and a hostile environment during this passage could have a deleterious effect on the fertilized ovum. A markedly shortened time taken by the tubal passage of the fertilized ovum seems to be at least one, if not the principal, mode of action of intrauterine devices (Mastroianni and Hongsonand, 1964), and it is at least conceivable that certain steroids also influence the motility and/or secretions of the Fallopian tube.

Thus, for the time being, a possible effect of oral contraceptives on the Fallopian tubes can neither be ascertained nor excluded.

\section{Ovarian Reaction to Gonadotrophins}

That oral contraceptives may inhibit the ovarian response to gonadotrophins was suggested by the fact that in mice and rats treated with gonadotrophins ovulation is prevented by the simultaneous administration of norethynodrel (Purshottam et al., 1961 ; France and Pincus, 1964) and lynoestrenol (Overbeek et al., 1962), respectively. Indeed, it has been reported that the administration of norethisterone acetate (Staemmler and Staemmler, 1960 ; Staemmler, 1964), Provera ethynyloestradiol (Lunenfeld et al., 1963), or the enol ethers of norethisterone and ethynyloestradiol (Hecht-Lucari, 1964) suppressed the ovarian reaction of patients treated with human gonadotrophins. ${ }^{2}$

On the other hand, Taymor (1964a) found that $5 \mathrm{mg}$. of norethisterone acetate given daily exerted no effect on the gonadotrophin-induced ovarian reaction, and Bettendorf (1962) reported that not even a daily dose of $20 \mathrm{mg}$. of this compound could inhibit the ovarian response to human pituitary gonadotrophins.

Johannisson et al. (1965) administered to five amenorrhoeic women in three experiments a daily dose of $12 \mathrm{mg}$. of norethisterone

2 Inhibition or decrease of ovarian reaction to exogenous gonadotrophins by naturally occurring steroids, such a progesterone (Gemzell et al., 1960 Staemmler, 1964) and testosterone (Diczfalusy et al., 1963), was alse reported, but the poor reproducibility f the effect was repeatedly cmily of the effect was repeatedly emphasized (Diczfalusy et al. 
acetate together with $150 \mu \mathrm{g}$. of ethynyloestradiol, and in five experiments $5 \mathrm{mg}$. of Provera together with $75 \mu \mathrm{g}$. of ethynyloestradiol. As shown in the examples in Figs. 3 and 4 , in none of the experiments was it possible to abolish the ovarian steroid response to a standardized dose of human menopausal gonadotrophin. ${ }^{3}$

Although the available evidence may seem controversial to the reader, in my opinion it is unlikely that suppression of ovarian points employed in the methods estimating "total gonadotrophin" respond to both F.S.H. and L.H., and, furthermore, that the different strains of animals react differently to the effect of the same F.S.H./L.H. ratio (Brown and Billewicz, 1962 ; Diczfalusy et al., 1964).

Let us assume for a moment that the pill inhibited L.H. but not F.S.H. output. Bioassays on animals sensitive to L.H. but less sensitive to F.S.H. would then indicate a decreased output

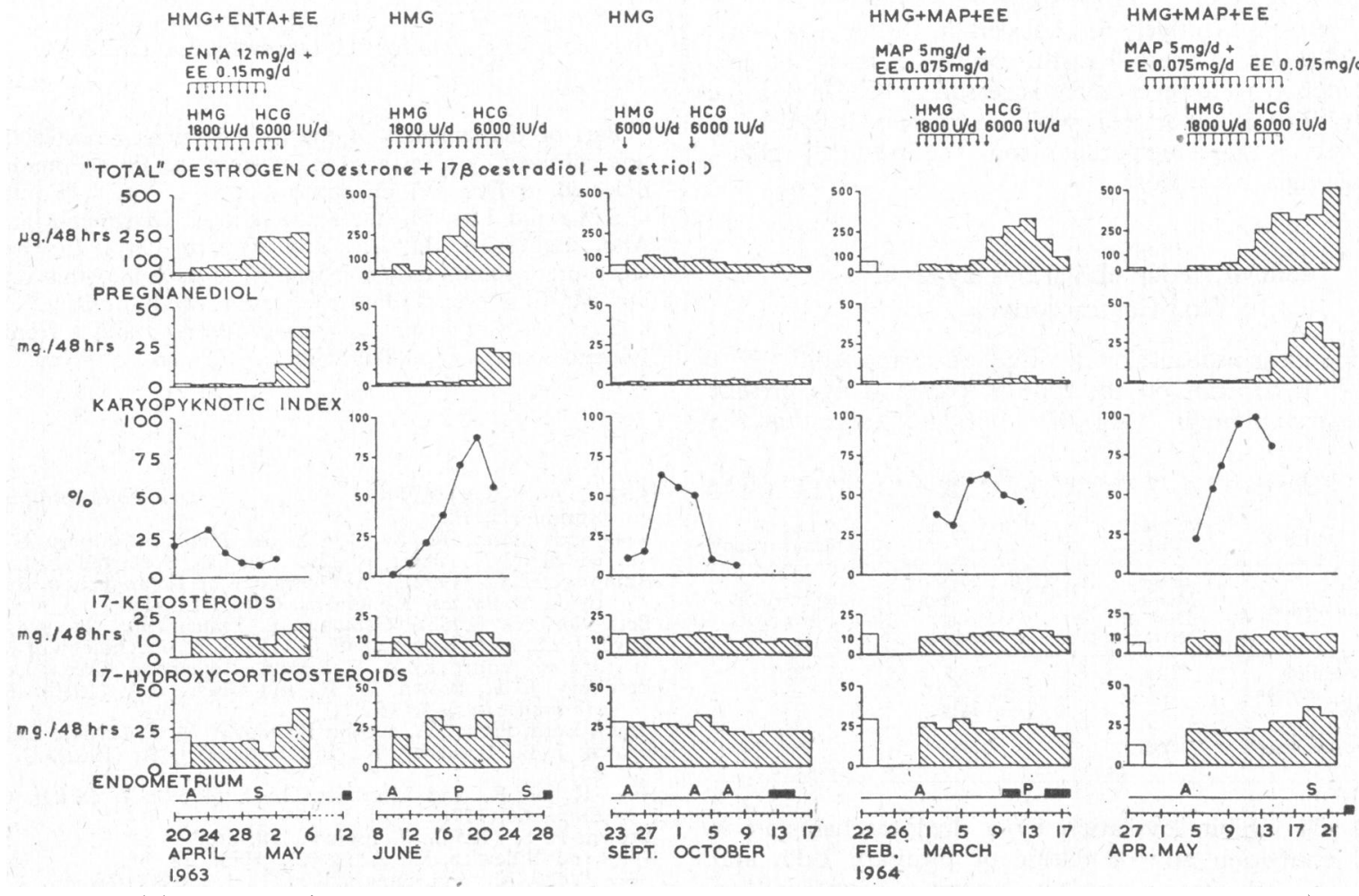

Fig. 4.- Clinical and steroid metabolic effects of human menopausal gonadotrophin (HMG) in a patient with secondary amenorrhoea when treated simultaneously with various oral contraceptive steroid combinations. For explanations see legend to Fig. 3. (According to Johannisson et al., 1965.)

response to endogenous gonadotrophic stimulation should play a major part in the mode of action of oral contraceptives.

\section{Pituitary Inhibition}

That the usual " classical " formulations of oral contraceptives inhibit ovulation is well established, and is indicated inter alia by the absence of the luteal-phase increase in urinary pregnanediol excretion-see Pincus (1959), Brown et al. (1962), and Goldzieher et al. (1962a, 1964)-as well as by the absence of a fresh corpus luteum from the ovaries of women treated with such compounds-see Rock et al. (1957), Matsumoto et al. (1960), Östergaard (1963), Lauweryns and Férin (1964), and Ryan et al. (1964).

It would seem logical that in these cases ovulation inhibition would take place via a suppression of the synthesis and release of pituitary gonadotrophins. However, estimation of the urinary excretion of " total gonadotrophin" gave seemingly conflicting results ; some investigators did not find a decrease in "total gonadotrophin" excretion-for example, Matsumoto et al. (1960), Rosemberg and Engel (1960), Albert and Smith (1961), and Brown et al. (1962)-whereas others did-for example, Feldman and Carter (1960), Martin and Cuningham (1961), Buchholz et al. (1962, 1964), Lin et al. (1964), and Taymor (1964b). In my opinion the most probable reason for this discrepancy should be sought in the fact that the endThe daily dose of gonadotrophin administered in these experiments
corresponds to 260 I.U. of F.S.H. activity and 170 I.U. of L.H. activity. of " total gonadotrophin," whereas estimations in animals more sensitive to F.S.H. than to L.H. could show a more or less unchanged urinary gonadotrophin level.

That this might be the case is suggested by the recent results of several investigators, who used more specific methods to estimate urinary L.H. excretion. Thus it was demonstrated by Taymor (1964b) that norethisterone inhibits the urinary excretion of L.H.,4 but affects much less the output of "total gonadotrophin," and the recent data reported by Stevens and Vorys (1965b) indicate that the administration of several oral gestagens (such as norethynodrel and ethynodiol diacetate) will abolish the mid-cycle peak of L.H. excretion, ${ }^{5}$ but have relatively little effect on the output of F.S.H. It was also demonstrated, by the use of immunological assay methods, that oral contraceptives inhibit urinary L.H. excretion (Brown et al., 1964; Wide et al., 1965). It is of importance in this connexion to point out that the effect of oestrogen on the release of L.H. is a function of the dose administered and that small doses of oestrogen stimulate rather than inhibit L.H. excretion (Funnell et al., 1951 ; McArthur et al., 1961 ; Stevens and Vorys, 1965b), whereas high doses suppress ovulation, presumably by inhibiting both F.S.H. and L.H. (Sturgis and Albright, 1940 ; Goldzieher et al., 1963).

Thus, although obviously more information is needed, the balance of evidence indicates that synthetic gestagens and gestagen + oestrogen combinations inhibit ovulation via a The method of Greep et al. (1941) was employed, which utilizes the
ventral prostate weight in hypophysectomized immature rats. 
suppressive effect on the synthesis and/or release of pituitary L.H.

\section{"Rebound Effect"}

Discontinuation of various forms of oral contraception generally results in a post-treatment increase in fertility, reflected by a high pregnancy rate (Tyler and Olson, 1958; Pincus, 1959 ; Pincus et al., 1959 ; Goldzieher et al., 1962b, 1964 ; Brain et al., 1964). There seems to be little doubt that the pill can be used effectively to treat certain forms of sterility. The mode of action of the pill in this process is as yet incompletely understood. However, there is reason to believe that the increased fertility is associated with an increased formation and/or release of gonadotrophins from the pituitary gland, which is no longer inhibited.

\section{Mode of Action of Various Types of Oral Contraceptives}

What is the most probable mode of action of the "pill" ? I believe that this depends on the type of pill, and my present concept is summarized in Table II. It is suggested that the

TABLE II.-Suggested Mode of Action of Various Oral Contraceptives

\begin{tabular}{c|c|c|c}
\hline Type: & $\begin{array}{c}\text { "Classical } \\
\text { Pill" }\end{array}$ & $\begin{array}{c}\text { "Sequential } \\
\text { Pill" }\end{array}$ & $\begin{array}{c}\text { "Luteal } \\
\text { Supplementation" }\end{array}$ \\
\cline { 2 - 3 } Composition: & $\begin{array}{c}\text { Gestagen + } \\
\text { Medium } \\
\text { Dose of } \\
\text { Oestrogen }\end{array}$ & $\begin{array}{c}\text { Higher Dose of } \\
\text { Oestogen Allone } \\
\text { +Oestrogen } \\
\text { +Gestagen }\end{array}$ & $\begin{array}{c}\text { Low Dose of } \\
\text { Gestagen Alone }\end{array}$ \\
\hline $\begin{array}{c}\text { Days of administration } \\
\text { Gonadotrophin-inhibition }\end{array}$ & $\begin{array}{c}21 \\
\text { L.H. }\end{array}$ & $\begin{array}{c}15+5 \\
\text { Both F.S.H. } \\
\text { and L.H. } \\
\text { ?.H. } \\
\text { No }\end{array}$ & $\begin{array}{c}30 \\
\text { None }\end{array}$ \\
$\begin{array}{c}\text { Effect on endometrium } \\
\text { Effect on cervical mucus }\end{array}$ & Yes & $\begin{array}{c}? \\
\text { Nes }\end{array}$ & \\
\hline
\end{tabular}

"classical" pill inhibits ovulation by a dual mechanism; it inhibits the formation and/or release of pituitary L.H. and renders the cervical mucus hostile to sperm penetration. In the " sequential " form of oral contraception (Goldzieher et al., 1963, 1964 ; Mears, 1964) the mode of action seems to be different ; provided a high enough dose of oestrogen is given, it will be sufficient per se to inhibit both F.S.H. and L.H. excretion, and the gestagen component will only be needed to ensure a better shedding of the endometrium. However, since "escape" ovulations were observed by the use of this treatment, without any pregnancies (Goldzieher et al., 1964), it is possible also that the "sequential" pill has an additional point of attack. In the case of low-level luteal supplementation (Rudel and Martinez-Manautou, 1965) inhibition of ovulation seems to be the exception rather than the rule. In this case a direct effect on the cervical mucus and/or endometrium (and perhaps also on the Fallopian tube) is postulated.

\section{Conclusion}

Finally, it is emphasized that the above considerations do not represent in any respect " facts established beyond any reasonable doubt," but rather vague present concepts. Several uncertainties are involved in these concepts, and it is possible that future research will reveal that they were in part erroneous. However, we have to remember that the nature of science is continuously self-correcting, and we have to learn to kive with uncertainties, especially in the medical profession.

\section{Summary}

The exact mode of action of oral contraceptives is incompletely understood at present. It is suggested that the "classical" pill (various gestagen-oestrogen combinations) has at least two points of attack: it inhibits ovulation by blocking the release of luteinizing hormone, and it renders the cervical mucus hostile to sperm penetration.

It is likely that the "sequential" pill inhibits ovulation by suppressing the release of both follicle-stimulating hormone and luteinizing hormone. Whether it also has an additional point of action cannot be decided at present.

Finally, the pill based on "low-level luteal supplementation " is capable of controlling fertility without inhibiting ovulation. In this case changes in the endometrium and/or cervical mucus may be responsible for the contraceptive effect.

Part of the expenses of the investigations reported in this paper was defrayed by a research grant from the Ford Foundation. I am indebted to Drs. W. C. Stevens and N. Vorys (Columbus, Ohio, U.S.A.) and Drs. H. W. Rudel and J. Martinez-Manautou (Palo Alto, California, U.S.A., and Mexico City) for permission to incorporate some of their unpublished data into this review, and to Dr. M. E. Davis, Editor of Fertility and Sterility (Chicago, Ill., U.S.A.) for permission to reproduce Figs. 3 and 4 from a paper by Johannisson et al. published in Fertility and Sterility.

\section{REFERENCES}

Albert, A. (editor) (1961). Human Pituitary Gonadotropins. Thomas, Springfield, II

and Smith, R. A. (1961). In Human Pituitary Gonadotrapins, edited by A. Albert, p. 239. Thomas, Springfield, III.

Amoroso, E. C. (1952). In Physiology of Reproduction, 3rd ed., edited by A. S. Parkes. Longmans, Green, London.

Bettendorf, G. (1962). Geburtsh. u. Frauenheilk., 22, 928.

Boyd, J. D., and Hamilton, W. J. (1952). In Physiology of Reproduction, 3rd ed., edited by A. S. Parkes. Longmans, Green, London.

Bradbury, J. T., Brown, W. E., and Gray, L. A. (1950). Recent Progr. Hormone Res., $5,151$.

Brain, Lord, Parkes, A. S., and Bishop, P. M. F. (1964). Lancet, 2, 1329.

Brown, J. B., Fotherby, K., and Loraine, J. A. (1962). F. Endocr., 25 331

Kellar, R. and Matthew, G. D. (1959). F. Obstet. Gynaec. Brit. Emp., 66, 177.

Brown, P. S. (1959). F. Endocr., 18, 46.

- and Billewicz, W. Z. (1962). Ibid., 24, 65.

Wells, M., and Cunningham, F. J.'(1964). Lancet, 2, 446

Buchholz, R. (1957). Z. ges. exp. Med., 128, 219

Nocke, L., and Nocke, W. (1962). Geburtsh. u. Frauenheilk., 22 923.

. Int. Fert., 9,231.

Diczfalusy, E., and Heinrichs, H. D. (1956). Arch. Gynäk., 187, 556 Johannisson, E., Tillinger, K.-G., and Bettendorf, G. (1963). ₹. int. Fed. Gynec. Obstet., 1, 145 .

p. (1964). Acta endocr. (Kbh.), 45, Suppl. No. 90 p. 35

and Lauritzen, C. (1961). Oestrogene beim Menschen. Springer, Berlin.

Feldman, E. B., and Carter, A. C. (1960). 7. clin. Endocr., $20,842$. Férin, J. (1964). In Les fonctions du col utérin, pp. 135-138. Masson,

France, E. S., and Pincus, G. (1964). Endocrinology, 75, 359.

Fukushima, M., Stevens, V. C., Gantt, C. L., Vorys, N. (1964). F. clin. Endocr., 24, 205.

Funnell, J. W., Keaty, C., and Hellbaum, A. A. (1951). 7. clin. Endocr.

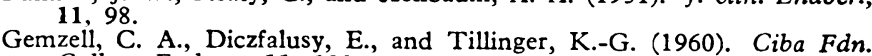
Colloq. Endocr., 11, 191 .

Goldzieher, J. W., Moses, L. E., and Ellis, L. T. (1962a). F. Amer. med. Ass., 180, 359.

- Rice-Wray, E., Schultz-Contreras, M., and Aranda-Rosell, A. (1962b). Amer.' F. Obstet. Gynec., 84, 1474.

Martinez-Manautou, J., Livingston, N. B., Moses, L. E., and RiceWray, E. (1963). West. F. Surg., 71, 187

Becerra, C., Gual, C., Livingston, N. B., iun., Maqueo, M., Moses, L. E., and Tietze, C.'(1964). Amer. F. Obstet. Gynec., 90, 404.

Greenblatt, R. B. (1959). Fed. Proc., 18, 1055.

Greep, R. O., VanDyke, H. B., and Čhow, B. F. (1941). Proc. Soc. exp. Bio!. (N.Y.), 46, 644 . Biol. (N.Y.), 46, 644. Sience and the Safe Period. Williams and
Hartman, C. G. (1962). Science
Wilkins, Baltimore.

Hecht-Lucari, G. (1964). Int. F. Fert., 9, 205.

Ishikawa, M., Fujii, K., Furusawa, Y., Kobayashi, T., Makino, T. Matsumoto, S., Takashima, T., and Takeuchi, S. (1957). F. Fap. Family Plann. Ass., 2, 51 . Quoted by Pincus (1959). Johannisson, E.. Tillinger, K.-G., and Diczfalusy, E. (1965). Fert.
Steril., 16, 292.

Lauweryns, J., and Férin, J. (1964). Int. f. Fert., 9, 35.

Lin, T. J., Durkin, J. W., and Kim, Y. J. (1964). Curr. ther. Res., 6 ,

Loraine, J. A. (1958). The Clinical Appiication of Hormone Assay. Livingstone, Edinburgh

Lunenfeld, B., Sulimovici, S., and Rabau, E. (1963). F. clin. Endocr., 23, 391. 
McArthur, J. W., Worcester, J., and Ingersoll, F. M. (1958). Ibid., 18,1186

A. Albert, p. 210. Thomas, Springfield, Ill

Maqueo M. Perez-Vega, E., Goldzieher, J. W., Martinez-Manautou, J. and Rudel, H. (1963). Amer. 尹. Obstet. Gynec., 85, 427.

and Rudel, H. (1963). Amer. F. Obstet. Gynec., 85, 427. 90, 395 .

Martin, L., and Cuningham, K. (1961). In Human Pituitary Gonadotropins, edited by A. Albert, p. 226. Thomas, Springfield, Ill.

Mastroianni, L., and Hongsonand, C. (1964). Paper presented at the Second International Conference on Intra-Uterine Contraception, 2 October 1964. Population Council N.Y.

Matsumoto, S., Ito, T., and Inoue, S. (1960). Geburtsh. u. Frauenheilk., 20, 250.

Mears, E. (1964). Paper presented at the Second International Congress of Endocrinology, London, 17-22 August 1964.

- (1965). "The Ċlinical Application of Oral Contraceptions," in The Proceedings of the Symposium on Agents Affecting Fertility, edited by C. R. Austin and J. S. Perry. Biological Council, Churchill,

Östergaard, E. (1963). Paper presented at the Symposium on Ovarian Inhibition by Progestogens in the Woman, Brussels 2-3 March 1963. International Ferulity Association.

Overbeek, G. A., Madjerek, Z., and de Visser, J. (1962). Acta endocr. $(K b h), 41,$.351 .

Parlow, A. F. (1961). In Human Pituitary Gonadotropins, edited by A. Albert, p. 300. Thomas, Springfield, Ill.

Pincus, G. (1955). Proceedings of the Sth International Conference on Planned Parenthood, I.P.P.F., Tokyo, p. 175. I.P.P.F., London. Planned Parenthood, I.P.P.F., Tokyo, p. 175. 1.P.P.

- (1956). Acta endocr. (Kbh.), Suppl.
- Rock, J., and Garcia, C. R. (1959). Proceedings of the 6th Internatzonal Conference on Planned Parenthood, New Delhi, p. 216. I.P.P.F., London.

Purshottam, N., Mason, M. M., and Pincus, G. (1961). Fert. Steril., 12, 346.

Rice-Wray, E., Aranda-Rosell, A., Maqueo, M., and Goldzieher, J. W. (1963). Amer. J. Obstet. Gynec., 87, 429

Rock, J., Garcia, C. R., and Pincus, G. (1957). Recent Progr. Hormone Res., 13,323

Rosemberg, E., and Engel, I. (1960). F. clin. Endocr., 20, 1576.

Rudel, H. W., and Martinez-Manautou, J. (1965). Paper presented at the Meeting of the American Society for the Study of Sterility, San Francisco, 2-4 April 1965.

Ryan, G. M., Craig, J., and Reid, D. E. (1964). Amer. F. Obstet. Gynec., $90,715$.

Schmidt-Elmendorff, H. (1965). Paper presented at the Meeting of the Mittelrheinischer Gesellschaft für Gynäkologie, Frankfurt.

Staemmler, H.-J. (1964). Die gestörte Regelung der Ovarialfunktion, pp. 184-189. Springer, Berlin

and Staemmler, H. (1960). Arch. Gynäk., 194, 183.

Stevens, V. C., and Vorys, N. (1965a). To be published.

Sturgis, $S$ (1965b). To be published.

rgis, S. H. (1961). In Control of Ovulation, edited by C. A. Villee, p. 213. Pergamon Press, New York.

Tayd Albright, F. (1940). Endocrinology, 26, 68.

Taymor, M. L. (1964a). Paper presented at the Second International Congress of Endocrinology, London, 17-22 August 1964.

(1964b). 7. clin. Endocr., 24, 803.

Tyler, E. T., and Olson, H. J. (1958). Ann. N.Y. Acad. Sci., 71, 704.

Wide, L., and Gemzell, C. (1962). Acta endocr. (Kbh.), 39, 539.

Zañartu, J. (1964). Int. Ұ. Fert., 9, 225.

\title{
Toxicity of Motor Neurone Disease Serum for Myelin in Tissue Culture
}

\author{
E. J. FIELD,* M.D., PH.D., M.S., M.R.C.P. ; D. HUGHES, † B.SC.
}

[With Special Plate]

Brit. med. F., 1965, 2, 1399-1401

The serum of rabbits with experimental allergic encephalomyelitis is known to contain substances which produce demyelination in cultures of newborn rat cerebellum (Bornstein and Appel, 1961). Although the evidence is far from secure, experimental allergic encephalomyelitis is commonly regarded as a "model" for human multiple sclerosis, and serum from patients with this disease has been claimed to possess a similar demyelinating activity (Bornstein, 1963). The present work reports a high proportion of positive results from serum of cases of motor neurone disease.

\section{Material and Methods}

Cases of motor neurone disease which had been subjected to careful diagnostic scrutiny for another purpose were investigated (Vejiajiva, Foster, and Miller, 1965). Sera were divided into four or five aliquots for separate testing and stored at $-65^{\circ} \mathrm{C}$. for not longer than two months before use.

Explants of newborn rat cerebellum were set up on coverslips coated with rat-tail collagen and grown at $35^{\circ} \mathrm{C}$. in roller tubes for 18 to 21 days. The nutrient medium comprised Simm's balanced salt solution 40\% ; Parker 199 medium (Glaxo) $5 \%$; bovine serum ultrafiltrate (Microbiological Associates, Bethesda, Md) $25 \%$; human ascitic fluid $25 \%$; chick embryo extract (nine days in ovo) $5 \%$. Glucose was added to a final concentration of about $600 \mathrm{mg} . / 100 \mathrm{ml}$. and $\mathrm{pH}$ was maintained within the range 6.9-7.1 by adjustment with $\mathrm{CO}_{2}$ as required. Cultures were screened in bright field or phase-contrast illumi-

- Honorary Director, Medical Research Council Demyelinating Diseases Research Unit ; Neuropathologist, Royal Victoria Infirmary and University of Newcastle. † Technical Officer. nation, and those quite free from degenerative or fatty change were selected for testing purposes.

Tests were carried out in either a Maximow or an opticalglass viewing-chamber (Rosenthal, New York), maintained at $35^{\circ} \mathrm{C}$. on a hot stage ; or they were carried out in chambers kept in the incubator and examined at intervals. In this way it was possible to obtain an overall view of the culture and revert to a specific field in order to record the sequence of changes photographically.

In testing each serum the following preparations were set up : (a) culture plus serum under test ( $25 \%$ in nutrient fluid) and (b) culture plus normal human serum ( $25 \%$ in nutrient fluid).

As an additional control, culture plus nutrient fluid alone was set up in many cases. Two preparations of $(a)$ and $(b)$ were set up for each test ; occasionally three. Altogether 101 cultures of $(a), 63$ of $(b)$, and 40 with nutrient fluid alone were set up, so that more than 200 cultures were used in all. Myelotoxicity of serum is known to be complement-dependent (Bornstein, 1963), and in some early additional experiments fresh guinea-pig serum was added as a source of complement. In these cases additional controls were set up to establish the non-toxicity of the guineapig serum. Later, however, it was found unnecessary to introduce fresh guinea-pig serum, since direct estimation showed adequate complement levels to remain in the stored human sera. At the conclusion of a test the culture was fixed in formolsaline and the axis cylinders were impregnated by the method of Bodian.

Altogether serum was tested from 21 patients in whom the diagnosis of motor neurone disease was based upon the most stringent diagnostic criteria, five in whom the diagnosis was highly probable, and 20 normal subjects. A total of 204 cultures was examined. 